\title{
The impact of job satisfaction on employee performance through organizational commitment as intervening variables: A survey on employees of Mitra Swalayan
}

\section{Kartasura}

O impacto da satisfação no trabalho no desempenho dos funcionários por meio do

comprometimento organizacional como variáveis intervenientes: Uma pesquisa com funcionários da Mitra Swalayan Kartasura

El impacto de la satisfacción laboral en el desempeño de los empleados a través del compromiso organizacional como variables intervinientes: Una encuesta a los empleados de Mitra Swalayan

\section{Kartasura}

Received: 05/04/2021 | Reviewed: 05/10/2021 | Accept: 05/18/2021 | Published: 06/02/2021

\author{
Suprayitno \\ ORCID: https://orcid.org/0000-0001-5433-3159 \\ Fakultas Ekonomi Universitas Slamet Riyadi, Indonesia \\ E-mail: suprayitno29@yahoo.co.id \\ Lamidi \\ ORCID: https://orcid.org/0000-0002-2015-8126 \\ Fakultas Ekonomi Universitas Slamet Riyadi, Indonesia \\ E-mail: lamidi71@gmail.com \\ Jeane Rosalia Qomariah \\ ORCID: https://orcid.org/0000-0002-8337-6083 \\ Fakultas Ekonomi Universitas Slamet Riyadi, Indonesia \\ E-mail: jeanerosaliaqoamariah19@gmail.com
}

\begin{abstract}
Mitra Swalayan Kartasura is a private company engaged in the retail sector to fulfill basic needs. This objective is to address the impact of satisfaction on commitment to organizational commitment, to respond to the significance of the impact of the organization on employee performance, to indicate the significance of the impact of employee performance on satisfaction and whether the organization can mediate employee job satisfaction. This type of research uses the census method for Mitra Swalayan Kartasura employees. This research uses qualitative data and quantitative data. Meanwhile, the data source uses primary data and secondary data. The population is all employees of Mitra Swalayan Kartasura who assess 85 employees. The sample in this study were 85 employees with the census method. The data analysis technique used multiple regression test, $t$ test, $F$ test, indirect effect test, path analysis and coefficient of determination. The results of the study indicate that job satisfaction can have a positive and significant effect on organizational commitment, there is no positive and significant influence between organizational commitment on employee performance, job satisfaction can have a positive and significant effect on employee performance and in this study it cannot prove that organizational commitment. mediate job satisfaction on employee performance.
\end{abstract}

Keywords: Job satisfaction; Organizational commitment; Employee performance.

\section{Resumo}

Mitra Swalayan Kartasura é uma empresa privada que atua no setor de varejo para atender às necessidades básicas. Este objetivo é abordar o impacto da satisfação no compromisso com o compromisso organizacional, para responder à importância do impacto da organização no desempenho do funcionário, para indicar a importância do impacto do desempenho do funcionário na satisfação e se a organização pode mediar o trabalho do funcionário satisfação. Este tipo de pesquisa usa o método do censo para funcionários da Mitra Swalayan Kartasura. Esta pesquisa utiliza dados qualitativos e dados quantitativos. Enquanto isso, a fonte de dados usa dados primários e dados secundários. A população é formada por todos os funcionários da Mitra Swalayan Kartasura que avaliam 85 funcionários. A amostra deste estudo foi de 85 funcionários com o método censitário. A técnica de análise de dados utilizou teste de regressão múltipla, teste $\mathrm{t}$, teste $\mathrm{F}$, teste de efeito indireto, análise de caminho e coeficiente de determinação. Os resultados do estudo indicam que a satisfação no trabalho pode ter um efeito positivo e significativo no comprometimento 
organizacional, não há influência positiva e significativa entre o comprometimento organizacional no desempenho do funcionário, a satisfação no trabalho pode ter um efeito positivo e significativo no desempenho do funcionário e neste estudo não pode provar esse compromisso organizacional. mediar a satisfação no trabalho no desempenho do funcionário.

Palavras-chave: Satisfação no trabalho; Compromisso organizacional; Desempenho do funcionário.

\section{Resumen}

Mitra Swalayan Kartasura es una empresa privada que se dedica al sector minorista para satisfacer las necesidades básicas. Este objetivo es abordar el impacto de la satisfacción en el compromiso con el compromiso organizacional, responder a la importancia del impacto de la organización en el desempeño del empleado, indicar la importancia del impacto del desempeño del empleado en la satisfacción y si la organización puede mediar en el trabajo del empleado. satisfacción. Este tipo de investigación utiliza el método del censo para los empleados de Mitra Swalayan Kartasura. Esta investigación utiliza datos cualitativos y cuantitativos. Mientras tanto, la fuente de datos utiliza datos primarios y secundarios. La población son todos los empleados de Mitra Swalayan Kartasura que evalúan 85 empleados. La muestra en este estudio fueron 85 empleados con el método de censo. La técnica de análisis de datos utilizó prueba de regresión múltiple, prueba t, prueba $\mathrm{F}$, prueba de efectos indirectos, análisis de ruta y coeficiente de determinación. Los resultados del estudio indican que la satisfacción laboral puede tener un efecto positivo y significativo en el compromiso organizacional, no existe una influencia positiva y significativa entre el compromiso organizacional en el desempeño de los empleados, la satisfacción laboral puede tener un efecto positivo y significativo en el desempeño de los empleados y en este estudio no puede probar ese compromiso organizacional. mediar la satisfacción laboral en el desempeño de los empleados.

Palabras clave: Satisfacción laboral; Compromiso organizacional; Rendimiento de los empleados.

\section{Introduction}

Human resources are the most important thing of an organization, because it plays an important role in optimizing organizational activities (such as the extent to which the organization's strategy is executed and the time that can be allocated to achieve the assigned goals) (Criveanu \& Cârstina, 2018). Human resource management is a way of how goals affect the character and performance of employees in order to make the greatest contribution to achieve company goals (Alami et al., 2015).

Gibson inside Suparyadi (Suparyadi, 2015) stated that job satisfaction and job performance has been explained that job satisfaction affect a different result of job quality, in which employees satisfaction lead to productive work results, however, on the other hand, it will lead to job satisfaction due to other superior performance or work performance, when the result of work become useful if it provide satisfaction.

Most people often talk about job satisfaction because job satisfaction is related to fulfillment of every people needs at work (Willis, 2016). During their work, people can create satisfaction regarding the proper and fair compensation, carry out their preference of work, obtain support from coworkers and leaders, having a safe and comfortable work environment, and use their skills to the fullest. It is different if job satisfaction is more related to individual job, organizational commitment, which is the attitude of a person who is related to the organization as a whole (Ćulibrk et al., 2018). However, between job satisfaction and organizational commitment there is a correlation that generally unidirectional or positive, if an employee is satisfied with his job, usually he will have superior commitment to the place he works. In certain cases, the correlation between job satisfaction and organizational commitment can be unidirectional or negative (Suparyadi, 2015).

According to Luthans (2008) explain if there is a positive correlation between organizational commitment toward the results of organization, related to the superior performance, low employee turnover quality, and low alpha quality. A study found a good correlation between organizational commitment toward performance, therefore someone with low financial needs someone with higher financial.

According to the study of Saufa and Maryati (2017) it explained that there is a positive and significant impact toward job satisfaction to improve the organizational commitment. According to research of Ady and Harfa (2020), it proves that the job satisfaction variable has significant impact and positive coefficient value on organizational commitment. Research by 
Nanda and Hidayat (Nanda \& Hidajat, 2020) supports that job satisfaction directly has positive impact on organizational commitment, the results found that the existence of worker organizational commitment can increase the provision of superior job satisfaction, because the more superior job satisfaction is created by worker, the greater employee's organizational commitment. However, different research results are shown by Dhurup et al (2016) which states that "continuance commitment reflects a negative association with job satisfaction". And according to Dhurup et al (2016), it can be understood that ongoing commitment reflects negative relationship on job satisfaction.

According to research by Kusuma and Lina (2018), it was explained that their successfully confirmed the positive impact of employee satisfaction on employee performance, The results of this study adding the facts of employees who obtain a job satisfaction will provide a good and positive employee performance. According to the research by Rene and Wahyuni (2018) it explains that the job satisfaction supports a significant impact on individual performance. However, the different result obtained from Saufa and Maryati (2017) which stated that there has no effect of job satisfaction that can increased the Therefore, during their work, nurses has to own a good loyalty and have a serious manner of work by saving other people life.

The research by Nanda and Hidayat (2020) indicated that based on their research, organizational commitment has positive impact on employee performance. A research result by Ady and Harfa (2020) supports that the Organizational Commitment variable has significant effect and positive coefficient value on work performance. It is different with the research results of Suparto and Hardaya (2019) Organizational commitment do not have significant impact on work performance. Based on the research by Nanda and Hidajat (2020), it is explained that organizational commitment can mediate the impact of job satisfaction on employee performance. however the research result are not the same as shown by the research of Kusuma and Lina (2018) which explains that their research has not been able to show the role of employee commitment as intervening variable. a feeling of satisfaction with the work performance of an employee does not necessarily create any attachment to the company (Sageer et al., 2012). Employee satisfaction has not been able to increase the commitment to the organization and have not been able to increase any work performance (Bhatti \& Qureshi, 2007).

\section{Theoretical Framework}

Job satisfaction is the calculation of an activity whether it is interesting or not to be done. A Good job satisfaction can create organizational commitment (Bangun, 2012). Related to the analysis of Kusuma dan Lina (Kusuma \& Lina, 2018) who explained that this study was successful showing positive impact on employee satisfaction toward employee performance.

\section{H1: Job satisfaction has significant effect on employee performance.}

Organizational commitment defined as a measure of employee determination to the organization / company which characterizes their interest as a part of organization, behave well for organization, and continue to carry the company's brand image (Triatna, 2016). This is supported by research result by Arifhan Ady DJ, Akhdiari Harfa DJ (2020) which explains that Organizational Commitment variable has significant effect and positive coefficient value on performance. It is indicated that organizational commitment can encourage someone to obtain higher performance.

\section{H2: Organizational commitment has significant effect on employee performance.}

Robbins dan Counter (2018) Employee satisfaction (job satisfaction) refers to the attitude that employees often shows within their work, meanwhile Triatna (2016) explains job satisfaction as "the attitude of workers during their job is a result of their work perceptions". The results of this study were supported by Ari Deva Nanda, Taofik Hidajat (2020) which states that job satisfaction simultaneously has positive influence on organizational commitmentit can be proves that workers' organizational commitment can be better by providing the work satisfaction because the better work satisfaction, the better 
employee's organizational commitment.

\section{H3: Job satisfaction has significant effect on organizational commitment.}

Job satisfaction is a positive sense of work that obtained from consideration of its broad features (Robbins \& Judge, 2018). Serious job satisfaction can generate organizational commitment through serious intervening variables, the results of this study are supported by Ari Deva Nanda, Taofik Hidajat (2020) explains that job satisfaction has positive impact on employee performance through significant organizational commitment, then the implementation of job satisfaction can produce the best organizational commitment and organizational commitment results in a better work performance.

\section{H4: Organizational commitment mediates the effect of job satisfaction on employee performance.}

\section{Research Methodology}

This research uses the census method for Mitra Swalayan Kartasura employees. This research uses qualitative and quantitative data and the data source uses primary and secondary data. The population is every employees of Mitra Swalayan Kartasura, within the total amount of 85 employees. The sample in this study were 85 employees within the census method. Data analysis technique uses multiple regression test, $\mathrm{t}$ test, $\mathrm{F}$ test, indirect effect test, path analysis and coefficient of determination.

Based on the opinion of Bangun (2012) Job satisfaction is an evaluation of an activity whether it is interesting or not interesting. Robbins dan Judge (2018) divided the indicator of job satisfaction into four types include the job, current salary, relationships with superiors and co-workers.

Al Afghoni and Wahyudi inside Kusuma and Lina (2018) describes organizational commitment as the quality of achieving how long worker takes more specific side of an organization and achieves the existing goals, also willing to look after the members of organization. Meanwhile Mangkunegara divide the employee performance indicators into 5 types such as quality, quantity, implementation of tasks, responsibilities and initiatives (Mangkunegara, 2013). "Work performance is a ability that can be implemented based on knowledge, skills and the attitude to gain certain things (Hasibuan, 2010). Robbins and Judge divided the indicator of job satisfaction into four types consist of affective commitment, continuance commitment and normative commitment (Robbins \& Judge, 2018).

\section{Results}

The results of this study indicate that simple linear regression analysis can be made linear regression of $\mathrm{Y}=7,273+$ $0,308 \mathrm{X}+\mathrm{e}$. The interpretation of regression equation is:

Constant (a) within a positive parameter of 7,273 explain if job satisfaction (X) is equal to zero, that organizational commitment $(\mathrm{Y})$ is positive. The variable regression coefficient value (b) with positive parameters is 0.308 , the positive effect is unidirectional, it means that if job satisfaction $(\mathrm{X})$ increases or gets better, organizational commitment $(\mathrm{Y})$ can increase, in the other way if job satisfaction (X) decreases, organizational commitment $(\mathrm{Y})$ ) can decrease (Table 1).

Table 1. Simple linear regression test results.

\begin{tabular}{c|c|c|c|c|c}
\hline Model & $\mathrm{B}$ & Std. Eror & Beta & $\mathrm{T}$ & Sig. \\
\hline Constanta) & 7,273 & 1,901 & & 3,826 & 0,000 \\
\hline $\mathrm{X}$ & 0,308 & 0,049 & 0,565 & 8,231 & 0,000 \\
\hline \multicolumn{6}{c}{ Source: SPSS data (2021). } \\
\hline
\end{tabular}


The results of this study also prove that multiple linear regression test, produces a regression equation $\mathrm{Y}=6,115+$ $0,232 \mathrm{X}+0,199 \mathrm{Z}+\mathrm{e}$. The interpretation of regression equity is:

The constant (a) positive parameter of 6.115 means that if job satisfaction (X) is equal to zero, organizational commitment $(\mathrm{Z})$ is equal to zero and employee performance $(\mathrm{Y})$ is positive. The value of variable regression coefficient (b1) of variable job satisfaction $(\mathrm{X})$ is 0.232 positive means that job satisfaction $(\mathrm{X})$ is growing better, the employee performance (Y) can also increase, on the contrary, if job satisfaction (Z) decreases, employee performance (Y) will decrease within the assumtion of organizational commitment variable $(\mathrm{Z})$ is constant. Regression coefficient value (b2) of organizational commitment variable $(\mathrm{Z})$ is 0.119 positive, it means that if organizational commitment $(\mathrm{Z})$ increases or gets better, the employee performance (Y) will also increase. However, if organizational commitment (Z) decreases, employee performance (Y) will decrease, it assume that the job satisfaction variable (X) is constant.

Table 2. Multiple linear regression test results.

\begin{tabular}{cccccc}
\hline Model & B & Std. Eror & Beta & T & Sig. \\
\hline (Constanta) & 6,115 & 2,051 & & 2,982 & 0,004 \\
X & 0,232 & 0,060 & 0,429 & 3,889 & 0,000 \\
Z & 0,199 & 0,109 & 0,201 & 1,824 & 0,072 \\
\hline
\end{tabular}

Source: spss data result (2021).

Based on the results of $\mathrm{t}$ test model 1, it can be seen that the significant effect of each independent variable on dependent is described as following below:

\section{Job Satisfcation (X) toward organizational commitment (Z)}

Job satisfaction is obtained by the value of $\rho$-value (significance) $=0.000<0.05$ therefore H0 is rejected and Ha is accepted, it means that there is a significant effect of job satisfaction on organizational commitment. Therefore, H1 stated that "Job satisfaction $(\mathrm{X})$ has significant effect on organizational commitment $(\mathrm{Z})$ " is proven to be true.

Table 3. The results of $t$ test model 1 .

\begin{tabular}{cccccc}
\hline Model & B & Std. Eror & Beta & T & Sig. \\
\hline (Constanta) & 7,273 & 1,901 & & 3,826 & 0,000 \\
X & 0,308 & 0,049 & 0,565 & 6,231 & 0,000 \\
\hline
\end{tabular}

Source: spss data result (2021).

Meanwhile, from the results of t test model 2, it can be seen that significant effect of several independent variables on dependent variable as following below:

Job Satisfaction $(\mathrm{X})$ toward employee performance $(\mathrm{Y})$ Job satisfaction obtained $\rho$-value (significance) $=0.000<0.05$ therefore $\mathrm{HO}$ is rejected and $\mathrm{Ha}$ is accepted, it means that there is a significant effect of job satisfaction (X) on employee performance $(\mathrm{Y})$. H2 in this study which explains that "Job Satisfaction (X) has significant effect on Employee Performance $(\mathrm{Y})^{\prime \prime}$ is proven to be true.

\section{Organization Commitment (Z) toward economic performance $(Y)$}

Organizational commitment obtain a value of $\rho$-value (significance) $=0,072>0,05$ thus, H0 is accepted which means 
that there is no significant effect of Organizational commitment (Z) toward employee performance (Y). H3 in this study which explained that "Organizational Commitment (Z) has a significant effect on Employee Performance (Y)" can not be proven as true.

Table 4. the result of t-test model 2.

\begin{tabular}{cccccc}
\hline Model & B & Std. Eror & Beta & T & Sig. \\
\hline (Constanta) & 6,115 & 2,051 & & 2,982 & 0,004 \\
X & 0,232 & 0,060 & 0,429 & 3,889 & 0,000 \\
Z & 0,199 & 0,109 & 0,201 & 1,824 & 0,072 \\
\hline
\end{tabular}

Source: spss data result (2021).

Based on the table below, it is known that the magnitude of the $\mathrm{F}$ count indicated that the regression model has an $\mathrm{F}$ value of 19.425 and significance value (p-value) of $0.000<0.05$. Moreover, Ho is rejected and Ha is accepted, it means that the model is correct in predicting the impact of X (Job Satisfaction) and X3 (Organizational Commitment) on Y (Employee Performance).

Table 5. F test result.

\begin{tabular}{lccccc} 
Model & Sum of Square & Df & Mean Square & F & Sig. \\
\hline Regression & 144,435 & 2 & 72,217 & 19,425 & $0,000^{b}$ \\
Residual & 304,860 & 82 & 3,718 & & \\
Total & 449,294 & 84 & & & \\
\hline \multicolumn{5}{c}{ Source: spss data result (2021). }
\end{tabular}

The results of the table below indicated that the coefficient of determination (adjusted R Square) for this model is 0.305. It means that the contribution on the influence of independent variables $X$ (Job Satisfaction) and X3 (Organizational Commitment) on Y (Employee Performance) is $30.5 \%$. The rest $(100 \%-30.5 \%)=69.5 \%$ is explained by other variables outside the model such as work motivation, leadership and work discipline.

Table 6. $\mathrm{R}^{2}$ Determination test result.

\begin{tabular}{ccccc}
\hline Model & $R$ & $R$ Square & Adjusted $R$ Square & $\begin{array}{c}\text { Std. Error of the } \\
\text { Estimate }\end{array}$ \\
1 & $0,565^{\mathrm{a}}$ & 0,319 & 0,311 & 1,93849 \\
2 & $0,567^{\mathrm{a}}$ & 0,321 & 0,305 & 1,92816 \\
\hline
\end{tabular}

Source: The obtained data (2021).

$\mathrm{t}$-count value $(1,733)<\mathrm{t}$-tableb $=1.98861$ it can be concluded that Organizational Commitment $(\mathrm{Z})$ does not mediate the effect of Job Satisfaction (X) on Employee Performance (Y), H4 which explains that "Organizational Commitment (Z) mediates the effect of Job Satisfaction $(\mathrm{X})$ on Employee Performance $(\mathrm{Y})$ " does not proven to be true.

\section{Discussion}

The results of the study prove that there is a significant impact on job satisfaction (X) toward the organizational commitment (Z). Therefore, H1 which explains that "job satisfaction has significant effect on organizational commitment to employees of Mitra Swalayan Kartasura" is proven true. Suparyadi (2015) supports that there is a significant relation between 
satisfaction and organizational commitment, it means that employees who obtain a job satisfaction will have an organizational commitment to their organization/company. job satisfaction will lead to an effective ability to positively contribute to their company and it will gain an organizational goals. The employees did not expect to leave the company even though they receive the highest compensation offer than they receive from the current company. The results of this study also supported by previous research of Ady and Harfa (2020), Nanda and Hidayat (2020) and the research from Saufa and Maryati (2017) which explains that job satisfaction has positive and significant impact on organizational commitment.

The results of this study prove that there is no significant impact of organizational commitment $(\mathrm{Z})$ toward employee performance $(\mathrm{X})$. Therefore, $\mathrm{H} 2$ which explains that "organizational commitment has significant effect on employee performance of Mitra Swalayan Kartasura" is uncertain whether it is true or false. A study found a strong correlation between organizational commitment and performance for individual with low financial needs toward individual with higher financial needs. The results of this study are supported by previous research from Suparto and Hardaya (2019) which explains that organizational commitment does not have positive and significant impact on employee performance.

The results of this study explain that there is a significant impact on job satisfaction $(\mathrm{X})$ toward employee performance (Y). then $\mathrm{H} 3$ which explains that "job satisfaction has a significant effect on employee performance of Mitra Swalayan Kartasura" is proven to be true. This research supports Gibson's theory in Suparyadi (2015) which suggests that job satisfaction and work performance has reciprocal effect, it is explained that job satisfaction leads to quality performance, which means job satisfaction can make the workers be more productive. However, on different side there is also an incidence of job satisfaction that causes quality performance or work expertise, namely because of the acquisition of a profitable job, it will obtain job satisfaction. The results of this study supported by previous research from Ady and Harfa (2020), Nanda and Hidayat (2020), and also by previous research from Kusuma and Lina (2018) which states that job satisfaction has a positive and significant effect on employee performance.

The results of this study explain that there is no mediating impact of job satisfaction $(\mathrm{X})$ on employee performance (Y) through organizational commitment $(\mathrm{Z})$ as mediating variable, therefore $\mathrm{H} 4$ which explains that "organizational commitment mediates the effect of job satisfaction on employee performance of Mitra Swalayan Kartasura" has not proven to be true. This research does not support Suparyadi's (2015) theory which suggests that job satisfaction with organizational commitment has a correlation that is generally unidirectional or positive, which means if an employee is satisfied with his job, they will have a quality commitment to the company. In certain cases, the correlation between job satisfaction and organizational commitment can be unidirectional or negative. The results of this study are supported by previous research from Kusuma and Lina (2018) which explains that this research cannot justify the role of employee commitment as an intervening variable. satisfaction that arise from an employee regarding the company he works have not shown yet. Employee satisfaction has not received an increase regarding their commitment to the organization and has not been able to increase work performance.

\section{Conclusion}

Based on the results of this study, it was found that job satisfaction could have a positive and significant impact on organizational commitment, organizational commitment to employee performance has positive and insignificant effect, Job satisfaction on employee performance has positive and significant effect. in this study it cannot prove that organizational commitment mediates job satisfaction on employee performance.

The conclusion of this study explains that if the employees of Mitra Swalayan Kartasura are satisfied with their job, it will provide productive performance, produce maximum work and are always enthusiastic at work. However, Mitra Swalayan Kartasura employees have not been able to generate interest to stay and continue to work at Mitra Swalayan Kartasura. 


\section{References}

Ady, A., \& Harfa, A. (2020). Pengaruh Motivasi, Kepuasan Kerja, Komitmen Organisasional Terhadap Kinerja Perawat Di RSUD Majene. MANDAR: Management Development and Applied Research Journal, 2(2). https://doi.org/https://doi.org/10.31605/mandar.v2i2.713

Alami, R., Sohaei, R., Berneti, A. K. M., Younesi, A., Farnia, M., \& Mirzajani, H. (2015). The Effectiveness of Human Resource Management on Improving the Performance of Education Staff. International Journal of Business and Social Science, 6(5).

Bangun, W. (2012). Manajemen Sumber Daya Manusia. Erlangga.

Bhatti, K. K., \& Qureshi, T. M. (2007). Impact of Employee Participation on Job Satisfaction, Employee Commitment and Employee Productivity. International Review of Business Research Papers, 3(2), 54-68.

Criveanu, M. M., \& Cârstina, S. (2018). The importance of human resources within the strategic direction and organizational success. Proceedings of the International Conference on Business Excellence, 12(1), 229-240. https://doi.org/10.2478/picbe-2018-0021

Ćulibrk, J., Delić, M., Mitrović, S., \& Ćulibrk, D. (2018). Job Satisfaction, Organizational Commitment and Job Involvement: The Mediating Role of Job Involvement. Frontiers in Psychology, 9. https://doi.org/10.3389/fpsyg.2018.00132

Dhurup, M., Surujlal, J., \& Kabongo, D. M. (2016). Finding Synergic Relationships in Teamwork, Organizational Commitment and Job Satisfaction: A Case Study of a Construction Organization in a Developing Country. Procedia Economics and Finance, 35, 485-492. https://doi.org/10.1016/S22125671(16)00060-5

Hasibuan, M. S. . (2010). Manajemen Sumber Daya Manusia (Revisi). Bumi Aksara.

Kusuma, B. H., \& Lina, L. (2018). Pengaruh Kepuasan Karyawan Terhadap Kinerja Karyawan Dengan Komitmen Organisasi Sebagai Variabel Intervening (Survai Pada Perguruan Tinggi Swasta Di Wilayah Jakarta Barat). Jurnal Manajemen Maranatha, 17(2), 127. https://doi.org/10.28932/jmm.v17i2.798

Luthans, F., Norman, S. M., Avolio, B. J., \& Avey, J. B. (2008). The mediating role of psychological capital in the supportive organizational climateemployee performance relationship. Journal of Organizational Behavior, 29(2), 219-238. https://doi.org/10.1002/job.507

Mangkunegara, A. P. (2013). Manajemen Sumber Daya Manusia. Remaja Rosda Karya.

Nanda, A. D., \& Hidajat, T. (2020). Investigasi Tentang Budaya Organisasi, Kepuasan Kerja, Dan Kinerja Karyawan Melalui Komitmen Organisasi Karyawan Bank Bjb Cabang Tegal. Magisma: Jurnal Ilmiah Ekonomi Dan Bisnis, 8(1), 43-53. https://doi.org/10.35829/magisma.v1i1.68

Rene, R., \& Wahyuni, S. (2018). Pengaruh Work-Life Balance Terhadap Komitmen Organisasi, Kepuasan Kerja, Dan Motivasi Kerja Terhadap Kinerja Individu Pada Karyawan Perusahaan Asuransi Di Jakarta. Jurnal Manajemen Dan Bisnis Sriwijaya, 16(1), 53-63. https://doi.org/10.29259/jmbs.v16i1.6247

Robbins, S. P., \& Judge, T. A. (2018). Perilaku Organisasi (15th ed.). Pearson Education.

Sageer, A., Rafat, S., \& Agarwal, P. (2012). Identification of Variables Affecting Employee Satisfaction and Their Impact on the Organization. IOSR Journal of Business and Management (IOSR-JBM), 5(1), 32-39.

Saufa, J., \& Maryati, T. (2017). Dampak Kepuasan Kerja Dalam Peningkatan Kinerja Perawat Dengan Komitmen Organisasi Sebagai Variabel Intervening ( Studi Pada Perawat Rs Pku Muhammadiyah Gamping). JBTI : Jurnal Bisnis Teori Dan Implementasi, 8(2). https://doi.org/10.18196/bti.82094

Suparto, S., \& Hardaya, A. (2019). Analisis Kepemimpinan, Sarana Kerja terhadap Kinerja Pegawai Sekretariat Komisi Pemilihan Umum Kabupaten Klaten Komitmen Organisasi Sebagai Variabel Intervening. Juripol (Jurnal Institusi Politeknik Ganesha Medan), 2 (1), $50-67$.

Suparyadi. (2015). Manajemen Sumber Daya Manusia Menciptakan Keunggulan Bersaing Berbasis Kompetensi SDM. Andi Offset.

Triatna, C. (2016). Perilaku Organisasi Dalam Pendidikan. PT Remaja Rosdakarya.

Willis, R. M. (2016). Factors that Affect Job Satisfaction and WorkOutcomes of Virtual Workers. In Walden Dissertations and Doctoral Studies. Walden University. 